\title{
УНІВЕРСАЛЬНІ МІЖНАРОДНО-ПРАВОВІ МЕХАНІЗМИ ЗАБЕЗПЕЧЕННЯ ПРАВА НА МИРНІ ЗІБРАННЯ ТА ПРОБЛЕМАТИКА ЇХ ЕФЕКТИВНОСТІ
}

\author{
ДОРОШЕНКО Наталія Олексіївна - суддя Рівненського окружного \\ адміністративного суду, аспірант кафедри міжнародного права Львівського \\ національного університету імені Івана Франка
}

УДК 341.322.5

DOI 10.32782/LAW.UA.2021.3.26

Стаття присвячена дослідженню універсальних міжнародно-правових механізмів забезпечення права на мирні зібрання та проблематики їх еббективності в контексті виконання рішень Комітету ООН з прав людини на сучасному етапі розвитку міжнародного і начіонального права.

Ключові слова: право на мирні зібрання, Факультативний протокол до Міжнародного пакту про громадянсъкі $і$ політичні права 1966 року, міркування Комітету ООН з прав людини.

\section{Постановка проблеми}

Загально визнано, що ефективність регіональної європейської міжнародно-правової системи захисту прав та свобод людини зумовлена передусім обов'язковою силою судових рішень Европейського суду з прав людини. Однак на універсальному рівні сьогодні відсутні юридично обов'язкові міжнародно-правові норми, спрямовані, зокрема, на захист права на мирні зібрання. Водночас, у разі порушення цього права державою, яка не є учасником Європейської Конвенції про захист прав людини і основоположних свобод, особа може отримати міжнародно-правовий захист лише шляхом звернення до міжнародних організацій, компетенція яких поширюється на вирішення такого спору відповідно до умов чинних міжнародно-правових договорів. Питання пошуку шляхів підвищення ефективності сучасних універсальних міжнародно-пра- вових механізмів захисту конвенційного права є відкритим.

Аналіз останніх досліджень і публікацій

Теоретичні та практичні аспекти реалізації та захисту права на мирні зібрання були предметом дослідження низки вітчизняних вчених, зокрема, М.В. Буроменського, А.А. Федорової, Р.О. Куйбіди, М.І. Смоковича, Р.С. Мельника, О.В. Васькової, М.ภ. Середи та ін. Водночас, з точки зору міжнародного права, численні складові цієї проблеми досі залишаються нерозкритими, а нагальність питання їх практичної реалізації на національному рівні зумовлює необхідність у проведенні комплексного дослідження.

Метою дослідження $\epsilon$ аналіз правової природи міркувань Комітету ООН 3 прав людини за результатами розгляду індивідуальних повідомлень про порушення права на мирні зібрання, а також кореляція міжнародно-правових норм та норм національного законодавства в механізмі захисту конвенційного права.

\section{Виклад основного матеріалу дослідження}

Один з найважливіших міжнародних документів, який став підставою для розвитку механізмів міжнародно-правового захисту прав людини та громадянина, - Загальна Декларація прав людини, прийнята 10 груд- 
ня 1948 року Генеральною асамблеєю ООН, яка спрямована на розвиток статутних цілей ООН, зокрема утвердження віри в основні права людини, заохочення та розвиток поваги до прав людини й основоположних свобод для всіх, незважаючи на колір шкіри, стать, мову та релігію. Загальна Декларація за формою є резолюцією та згідно зі Статутом ООН має рекомендаційний, а не зобов’язуючий характер. Проте поступово вона стала важливою частиною міжнародного права, а іï норми - звичаєво-правовими стандартами поведінки держав, які впливають, серед іншого, на національні правотворчі процедури в сучасних державах. Для того, щоб надати Декларації універсальний характер, до неї включено тільки основні права та свободи, які визнавались в усіх суспільних системах.

Загальна Декларація не накладає на держави, які іiі підписали чи приєдналися пізніше до неї, ніяких зобов'язань стосовно закріплення та забезпечення цих прав i свобод у національному законодавстві та й у відносинах між собою. У ній визначається безпосередній зв'язок між досягненнями справедливості та загального миру в міжнародних відносинах і визнанням рівних i невід'ємних прав людини; визначається, що необхідною умовою забезпечення прав людини є верховенство права, встановлення такого режиму, за якого гарантується дотримання всіх основних прав і свобод людини, тобто режиму правової держави й громадянського суспільства як головних чинників забезпечення прав людини; закріплюється ідея про тісний зв'язок змісту декларації й зобов’язанням держав-членів ООН сприяти загальній повазі та дотриманню прав людини; визнається неподільність прав і свобод людини, їхня взаємопов'язаність та непротиставлюваність [2].

Свобода мирних зібрань визначена як одна 3 фундаментальних свобод у статті 20 Загальної декларації прав людини [3 ] : «Кожна людина має право на свободу мирних зборів та асоціацій».

Водночас проголошені Загальною Декларацією права та свободи людини потребували напрацювання правових механізмів захисту.
Такий механізм на міжнародному рівні започаткований у Міжнародному пакті про громадянські і політичні права [4], підписаному 16 грудня 1966 року ( Україною ратифіковано Указом Президії Верховної Ради N 2148-VIII від 19.10.1973), у преамбулі якого зазначено зобов'язання держав відповідно до Статуту Організації Об’єднаних Націй заохочувати права людини, нагадується про те, що кожна окрема людина має домагатися заохочення i дотримання цих прав, також визнається, що згідно із Загальною декларацією прав людини ідеал вільної людської особистості, яка користується громадянською і політичною свободою та свободою від страху і нестатків, може бути втіленим у життя тільки тоді, якщо будуть створені такі умови, за яких кожен може користуватися своїми економічними, соціальними і культурними правами, так як і своїми громадянськими і політичними правами.

За змістом частини першої статті 2 Пакту кожна держава, яка бере участь у цьому Пакті, взяла на себе зобов'язання поважати і забезпечувати всім, хто перебуває у межах іiі території та під іï юрисдикцією особам, права, визнані в цьому Пакті, без будь-якої різниці щодо раси, кольору шкіри, статі, мови, релігії, політичних чи інших переконань, національного чи соціального походження, майнового стану, народження чи іншої обставини.

Міжнародно-правовий механізм захисту прав людини грунтується на положеннях частин другої та третьої статті 2 Пакту, згідно 3 якими кожна держава-учасниця цього Пакту, у разі якщо сучасними законодавчими чи іншими заходами вже не передбачено таких заходів, зобов'язалася вжити потрібних заходів відповідно до своїх конституційних процедур і положень цього Пакту для вжиття таких законодавчих або інших заходів, які можуть виявитися необхідними для здійснення прав, визнаних у цьому Пакті.

Кожна держава, яка бере участь у цьому Пакті, зобов'язалася:

а) забезпечити будь - якій особі, права i свободи якої, визнані в цьому Пакті, порушено, ефективний засіб правового захисту, навіть коли це порушення було вчинене особами, що діяли як особи офіційні; 
b) забезпечити, щоб право на правовий захист для будь-якої особи, яка потребує такого захисту, визначала компетентна судова, адміністративна чи законодавча влада або будь-які інші компетентні органи, передбачені правовою системою держави, і розвивати можливості судового захисту;

с) забезпечити застосування компетентними органами засобів правового захисту, коли вони надаються.

Право на мирні зібрання закріплене в статті 21 Міжнародного пакту про громадянські і політичні права: «Визнається право на мирні збори. Користування цим правом не підлягає ніяким обмеженням, крім тих, які накладаються відповідно до закону $i$ які є необхідними в демократичному суспільстві в інтересах державної чи суспільної безпеки, громадсъкого порядку, охорони здоров'я і моральності населення або захисту прав та свобод іниих осіб».

Зауважимо, що в Міжнародному пакті про громадянські і політичні права викладені загальноприйняті мінімальні стандарти у сфері громадянських і політичних прав. Обов'язки, які покладаються на держави, що ратифікують Пакт або приєднуються до нього, підлягають виконанню одразу після того, як держава стає учасником Пакту.

Виконання Міжнародного пакту державами-учасницями контролюється Комітетом ООН з прав людини, який створений відповідно до статті 28 Пакту. До складу Комітету входять особи, які є громадянами держав-учасниць цього Пакту і мають високі моральні якості та визнану компетентність у галузі прав людини, причому береться до уваги корисність участі кількох осіб, що мають юридичний досвід.

Стаття 40 Пакту встановлює обов'язок держав, які беруть участь у цьому Пакті, подавати доповіді про вчинені заходи для втілення у життя прав, визнаних у цьому Пакті, і про прогрес, досягнутий у використанні цих прав: а) протягом одного року після набрання чинності цим Пактом щодо відповідних держав-учасниць; b) після цього в усіх випадках, коли того зажадає Комітет.

Усі доповіді подаються Генеральному секретареві Організації Об’єднаних Націй, який надсилає їх у Комітет для розгляду.У доповідях зазначаються чинники, коли такі є, що впливають на втілення у життя цього Пакту.

Комітет вивчає доповіді, подані державами, які беруть участь у цьому Пакті. Він надсилає державам-учасницям свої доповіді i такі зауваження загального порядку, які вважатиме доцільними.

Відповідно до статті 41 Міжнародного Пакту про громадянські і політичні права держава, яка бере участь у цьому Пакті, може в будь-який час заявити, що вона визнає компетенцію Комітету одержувати i розглядати повідомлення про те, що якась держава учасниця твердить, що інша держава-учасниця не виконує своїх зобов'язань за цим Пактом.

Водночас статтею 1 Факультативного протоколу до Міжнародного Пакту про громадянські і політичні права, підписаного 16 грудня 1966 року (Україна приєдналася до Факультативного протоколу згідно 3 Постановою Верховної ради N 582-XII від 25.12.1990; набуття чинності для України 25 жовтня 1991 року) [5] визначено, що держава-учасниця Пакту, яка стає учасницею цього Протоколу, визнає компетенцію Комітету приймати і розглядати повідомлення від осіб, які підпадають під його юрисдикцію і які твердять, що вони є жертвами порушень певною Державою - учасницею якогось із прав, викладених у Пакті.

Варто наголосити, що $з$ підписанням такого універсального конвенційного документа, як Міжнародний Пакт про громадянські і політичні права, та Факультативного протоколу до цього Пакту на міжнародному рівні не лише відбувається детальне тлумачення змістовного наповнення права на мирні зібрання, а й започатковано міжнародно-правовий механізм захисту цього права людини, свобода реалізації якого не підлягає жодним обмеженням за вільним розсудом держав.

у контексті досліджуваного питання варто зосередити увагу на Зауваженнях загального порядку Комітету з прав людини ООН № 37 (2020) про право на мирні зібрання (стаття 21) від 17 вересня 2020 року [6] , у яких наголошується, що завдяки основному праву людини на мирні зібрання окремі особи мають змогу висловлюва- 
ти свою думку колективно та брати участь у суспільному будівництві. Право на мирні зібрання важливе як самостійне право, бо захищає можливість людини здійснювати свою індивідуальну автономію спільно 3 іншими. Разом з іншими суміжними правами воно формує саму основу системи державного управління за участю громадян, базу якої становить демократія, права людини, верховенство права і плюралізм. Мирні збори можуть відігравати важливу роль у забезпеченні учасникам процесу можливості поширювати ідеї та амбіційні цілі в суспільній сфері та отримувати певну підтримку чи натрапляти на супротив таким ідеям і цілям.У тих випадках, коли під час мирних зібрань висловлюються скарги, виникає можливість врегулювати розбіжності на інклюзивній i мирній основі за широкої участі громадян. Крім того, право на мирні зібрання є цінним інструментом, який може використовуватися для визнання та реалізації широкого спектру інших прав, у тому числі економічних, соціальних і культурних прав. Це особливо важливо для маргіналізованих осіб та груп. Недотримання та незабезпечення права на мирні зібрання зазвичай $є$ ознакою репресій.

Право на мирні зібрання захищає ненасильницькі збори, що проводяться окремими особами 3 конкретною метою, головно для вираження поглядів. Це індивідуальне право, яке здійснюється в колективному порядку. Отже, невід'ємною частиною цього права є асоціативний елемент.

Право на мирні зібрання належить усім громадянам i негромадянам; його можуть використовувати іноземці, мігранти (за наявності чи відсутності документів), прохачі притулку, біженці й особи без громадянства.

Стаття 21 Міжнародного Пакту про громадянські і політичні права захищає мирні зібрання, де б вони не проводились: на свіжому повітрі, у приміщенні і в онлайн-режимі; у громадських місцях і місцях приватного використання; у разі поєднання кількох зазначених місць. Такі зібрання можуть мати різні форми: демонстрації, протести, збори, походи, мітинги, сидячі страйки, пам'ятні заходи, флешмоби тощо. Вони захищаються статтею 21 Пакту, безвідносно до того, чи здійснюються вони без пересування, як у випадку пікетування, чи динамічно, як у випадку ходи.

У багатьох випадках мирні зібрання не мають на меті досягнення спірних цілей i рідко створюють перешкоди чи взагалі не створюють їх. Вони можуть проводитися, наприклад, для святкування національного свята чи результатів спортивних заходів. Однак в інших випадках мирні зібрання можуть використовуватися для відстоювання ідеї чи мети, яка оспорюється. 3 огляду на масштаб чи характер вони можуть перешкоджати, зокрема, руху автотранспорту чи пішоходів, чи економічній діяльності. Однак ці наслідки, зумисні чи без наміру, не є підставою для позбавлення таких зібрань захисту, яким вони користуються. У тих межах,у яких той чи інший захід має наслідком означені перешкоди та ризики, вони мають регулюватися в рамках Пакту.

Визнання права на мирні зібрання покладає на держав-учасників відповідний обов'язок поважати та забезпечувати його реалізацію без будь-якої дискримінації. Для цього держави зобов'язані надати дозвіл на проведення таких зібрань без необгрунтованого втручання, сприяти здійсненню цього права та захищати їх учасників.

у другому реченні статті 21 Пакту передбачаються підстави для можливих обмежень, однак будь-які такі обмеження мають бути мінімальними. Фактично, обмеження можуть бути застосовані лише за певних умов.

у цитованих вище Зауваженнях загального порядку Комітету з прав людини ООН № 37 (2020) про право на мирні зібрання (стаття 21) від 17 вересня 2020 року також зазначено, що повний захист права на мирні зібрання можливий лише тоді, коли захищені й інші суміжні права, особливо свобода вираження поглядів, свобода асоціацій та участі в політичному житті. У випадках, коли поведінка окремих осіб призводить до позбавлення їх захисту, передбаченого в статті 21, наприклад, якщо вони вчиняють насильницькі акти, за ними зберігаються інші права, передбачені пактом, з урахуванням застосовних обмежень та умов. 
Дорошенко Н. - Універсальні міжнародно-правові механізми забезпечення права...

Способи проведення зібрань та їхній контекст $з$ плином часу змінюються. Це може вплинути на ставлення до них влади. Наприклад, позаяк нові комунікативні технології уможливлюють проведення зібрань повністю чи частково в онлайн-режимі і зазвичай є невід'ємним елементом організації зібрань 3 фізичною присутністю учасників, участі в них та їх моніторингу, то перешкоди таким комунікативним засобам можуть стати на заваді проведенню зібрань. Хоча технології спостереження можуть використовуватися для виявлення загрози застосування насильства i, отже, для захисту населення, вони також можуть порушити право на недоторканість приватного життя та інших прав учасників чи сторонніх осіб і так чинити стримувальний вплив. Крім того, загальнодоступний інформаційний простір i комунікативні платформи часто перебувають у власності приватних осіб та під іншими формами контролю. Такі міркування мають бути закладені в основу сучасного розуміння правової бази, потрібної у зв'язку зі статтею 21 Пакту.

Запроваджений Міжнародним Пактом про громадянські та політичні права та Факультативним протоколом до Пакту механізм захисту права мирні зібрання, визначеного в статті 21, нерозривно пов'язаний 3 виконаннями державами-учасницями своїх зобов’язань, а саме: поважати і забезпечувати всі визнані Пактом права (стаття 2 пункт 1 Пакту); вжити законодавчих та інших заходів для досягнення цієї мети (стаття 2 пункт 2 Пакту); забезпечити притягнення до відповідальності, а також надавати ефективні засоби правового захисту в разі порушення закріплених в Пакті прав (стаття 2 пункт 3 Пакту). Отже, зобов'язання державучасниць щодо права на мирні зібрання містить ці різні елементи, хоча в деяких випадках це право може обмежуватися відповідно до критеріїв, перерахованих у статті 21 .

Підхід органів влади до мирних зібрань і будь-які обмеження в принципі мають бути нейтральними щодо їхнього змісту і не повинні визначатися особистістю учасників чи їх ставленням до влади.

Обов'язок поважати та забезпечувати право мирних зібрань покладає на держави негативні та позитивні зобов'язання до, під час та після зібрань. Негативне зобов' язання полягає в тому, щоб не допускати невиправданого втручання в проведення мирних зібрань. Держави зобов’язані, наприклад, не забороняти, не обмежувати, не блокувати, не зривати, не розганяти мирні зібрання без суттєвих підстав, а також не застосовувати санкції до учасників чи організаторів без законних підстав.

Крім того, на держав-учасниць покладаються певні позитивні зобов'язання сприяти проведенню мирних зібрань і створенню умов для досягнення їхніми учасниками своєї мети. Отже, держави мають сприяти створенню умов для реалізації права на мирні зібрання без дискримінації та створити правову та інституційну базу, яка уможливить ефективну реалізацію цього права.

у відповідних випадках органам державної влади варто вжити певних заходів, наприклад, перекрити вулиці, змінити рух транспорту чи забезпечити безпеку. У разі потреби держави мають також захистити учасників від можливих зловживань зі сторони недержавних суб'єктів, зокрема, від втручання чи застосування насильства 3 боку інших представників громадськості, учасників контрдемонстрацій чи співробітників приватних охоронних підприємСтв.

Держави зобов'язані забезпечити, щоб закони та їх тлумачення і застосування не призводили до дискримінації в здійсненні права на мирні зібрання, наприклад, за ознаками раси, кольору шкіри, етнічної належності, віку, статі, мови, майнового стану, релігії, політичних чи інших переконань, національного чи соціального походження, належності до меншин, корінного чи іншого статусу, інвалідності, сексуальної орієнтації чи гендерної ідентичності чи іншого статусу. Особливих зусиль треба докласти для забезпечення рівного та ефективного заохочення та захисту права на мирні зібрання осіб, належних до груп, щодо яких застосовується чи застосовувалась дискримінація чи які стикаються 3 труднощами стосовно участі в зібраннях. Крім того, держави зобов'язані захищати учасників від усіх форм дискримінаційних зловживань і нападів. 


\section{Міжнародне право}

Право на мирні зібрання не відмежовує учасників від протестів з боку інших членів суспільства. Держави мають поважати і забезпечувати проведення контрдемонстрацій як повноцінних зібрань, однак не допускати безпідставного зриву тих зборів, проти яких вони спрямовані. Загалом держави мають дотримуватись нейтрального щодо змісту підходу до контрдемонстрацій та забезпечувати умови для їх проведення, наскільки це можливо, у межах видимості та чутності тих зібрань, проти яких вони спрямовані.

Можливість того, що мирне зібрання може спровокувати негативну реакцію чи навіть насильство з боку інших груп населення, не є достатньою підставою для заборони зібрання чи обмежень щодо нього. Держави зобов’язані вживати всіх розумних заходів, які не є несумірно обтяжливими, для захисту всіх учасників і забезпечення таких зібрань без порушення їх проведення.

Основу зобов'язання поважати та забезпечувати право мирних зібрань утворюють функціонуючі та прозорі правова система i система прийняття рішень. Норми внутрішнього права мають визнавати право на мирні зібрання, чітко регламентувати обов'язки та відповідальність усіх залучених державних органів і посадових осіб, узгоджуватися $з$ міжнародними стандартами та бути доступними населенню.

Відтак в умовах сьогодення при невідповідності національно-правових норм щодо права на мирні зібрання міжнародним стандартам та/або в разі недотримання чи свідомого ігнорування державами-учасницями Міжнародного Пакту про громадянські та політичні права своїх зобов'язань за статтею 21 Пакту (статтею 20 Загальної Декларації 3 прав людини), єдино можливий правовий механізм захисту цього права для індивідів пов'язаний зі зверненням до міжнародних судових установ чи міжнародних організацій, компетенція яких поширюється на вирішення таких спорів, згідно з умовами чинних міжнародно-правових договорів. Варто зазначити, що на універсальному рівні такою правомочністю наділений лише Комітет з прав людини ООН при вирішенні спорів осіб з державами-учасниками цього Пакту, які підписали Факультативний про- токол та визнали відповідну компетенцію Комітету з прав людини ООН.

Зміст доробку Комітету ООН з прав людини в контексті статті 21 Міжнародного Пакту є своєрідним індикатором, «лакмусовим папером» щодо рівня розвитку демократичних інститутів у суспільстві, дотримання в цілому громадянських і політичних прав державами-учасницями, виявом «больових точок» громадянського суспільства, внаслідок тиску на які органи державної влади діють свавільно, а часом і з елементами репресій.

Свідченням цьому є, зокрема, міркування, прийняті Комітетом ООН $з$ прав людини впродовж останніх років за розглядом численних звернень громадян Білорусі щодо порушення права на мирні зібрання.

Зокрема, у міркуваннях, прийнятих 23 липня 2020 року щодо повідомлення № 2461/2014, внесеного 7 травня 2014 року громадянами Білорусі Михайлом Тимошенко, Володимир Кацора, Василь Поляков та інші, які стверджували, що держава-учасник порушила їх права за статтями 19 та 21 Пакту внаслідок відмови муніципальної влади в дозволі на проведення пікетів, Комітет нагадав, що право на мирні зібрання, гарантоване статтею 21 Пакту, є одним 3 основних прав людини, надзвичайно важливим для публічного вираження поглядів i переконань особистості та необхідним у демократичному суспільстві. Це право дає змогу організувати мирне зібрання, у тім числі пікет, у громадському місці та брати в ньому участь. Організатори зібрання зазвичай мають право вибирати місце, де їх може бачити та чути цільова аудиторія, і будь-яке обмеження цього права неприпустиме, за винятком випадків, коли: а) воно застосовується відповідно до закону; і b) воно необхідне в демократичному суспільстві в інтересах національної та громадської безпеки, громадського порядку (ordre public), охорони здоров'я і моралі населення та захисту прав і свобод інших осіб. Коли державаучасник застосовує обмеження, щоб забезпечити рівновагу між правом окремої особи на зібрання та вищевказаними суспільними інтересами, їй треба головно керуватися метою сприяння реалізації цього права, а 
не прагнути без необхідності чи несумірно обмежувати його. Держава-учасник, отже, зобов'язана обгрунтувати обмеження права, захищеного статтею 21 Пакту (Поплавний проти Білорусі (CСPR/C/115/D/2019/2010), пункт 8.4.) [ 7] .

У міркуваннях від 25 березня 2015 року за результатами розгляду повідомленням№ 1949/2010 від 15 березня 2010 року громадян Білорусі Павла Козлова, Валерія Ільяша, Сергія Пстига, Марата Брашко, Романа Кисляка 3 приводу відмови влади в наданні дозволу на проведення пікету «проти байдужості чиновників», Комітет зауважив, що в цьому випадку автори просили про проведення пікету в пішохідній зоні міста Брест, щоб привернути увагу громадян до можливих систематичних порушень законодавства про звернення громадян з боку чиновників, однак їх прохання було відхилене. За таких обставин і за відсутності будь-яких роз'яснень з боку держави-учасниці Комітет вважає рішення органу влади держави-учасниці про відмову авторам повідомлення в праві на проведення мирного зібрання в громадському місці за їх вибором безпідставним. Комітет також відзначив, що національні органи влади не продемонстрували, як пікет в означеному місці може створити загрозу для державної та громадської безпеки, громадського порядку й охорони здоров'я чи моралі населення чи охорони прав і свобод інших осіб. Комітет відзначив, що фактична заборона зібрання в будьякому громадському місці в місті Брест, за винятком стадіону «Локомотив», невиправдано обмежує право на свободу зібрань. Тому Комітет дійшов висновку, що право авторів повідомлення відповідно до статті 21 Пакту було порушено [ 8] .

У міркуваннях від 19 липня 2018 року за повідомленням № 2230/2012 від 12 червня 2012 року Тетяни Северинець, громадянки Білорусі (справа про накладення адміністративного штрафу за проведення мирного зібрання без попереднього повідомлення), Комітет зазначив, що раніше в межах одного 3 повідомлень щодо вимог про повідомлення про проведення мирного зібрання Комітет вже висловлювався 3 цього приводу, що вони можуть бути сумісними 3 дозвільними обмеженнями, викладеними в статті 21 Пакту. Однак хоча система попередніх повідомлень може мати важливе значення для безпечного проведення публічних демонстрацій, «ії правозастосування не може ставати самоціллю». Будь-яке обмеження права на мирні зібрання має бути мотивоване державою-учасником у контексті другого речення статті 21. Це найбільш правильно у разі спонтанних демонстрацій, які за своєю природою не можуть бути поєднані з тривалою процедурою внесення попереднього повідомлення (наприклад, Кивенмаа проти Фінляндї (CCPR/C/50/D/412/1990), пункт 9.2.; Свропейський суд з прав людини, Анненков та інші проти Россї (заява № 31475/10), постанова від 25 жовтня 2017 року, пункт 131 d); Попова проти Російської Федераиії (CCPR/ C/122/D/2217/2012), пункт 7.5.) [9 ].

Варто зазначити, що рекомендаційний характер рішень Комітету ООН з прав людини за розглядом індивідуальних звернень та, як наслідок, відсутність обов'язкових міжнародно-правових механізмів захисту прав людини на універсальному рівні призводить до ігнорування окремими державами-учасницями підтверджених фактів порушення прав людини в цілому та права на мирні зібрання зокрема. I в такому разі вже йдеться не про відновлення порушеного права, а про становлення на національному рівні системи таких порушень, які окреслюються рамками національного закону.

Прикладом цьому слугують події останнього року в Республіці Білорусь, пов'язані 3 силовим розгоном протестних акцій та несанкціонованих масових заходів. Незважаючи на численні рекомендації Комітету ООН 3 прав людини, зокрема, у проаналізованих вище міркуваннях за зверненнями громадян Білорусі щодо необхідності приведення національного законодавства до міжнародно-правових стандартів, які забезпечують право на мирні зібрання, та неприпустимості його необгрунтованого обмеження, фактично на законодавчому рівні сусідньої держави тривають процеси посилення обмежень цього права та відповідальності за його реалізацію.

Так, з 1 березня цього року в Білорусі набув чинності новий Кодекс про адміні- 


\section{Міжнародне право}

стративні правопорушення, яким максимальний розмір штрафу за участь у несанкціонованому масовому заході збільшений 3 30 до 100 базових величин (з 870 до 2900 білоруських рублів, тобто понад 900 євро), а при повторних діях - 350 до 200 базових величин (з 1450 до 5800 рублів, тобто до 1800 євро). Максимальний термін адміністративного арешту за повторну участь у несанкціонованих акціях протягом року тепер становить від 15 до 30 діб (раніше було 25 діб). Крім того, виключено положення, згідно з яким за участь у незаконній акції можна було отримати попередження, а також запроваджено новий вид адміністративного стягнення - громадські роботи. Посилена адміністративна відповідальність за непокору співробітнику міліції. Зміни також передбачають штраф за використання, виготовлення, поширення «заборонених законодавчими актами прапорів, вимпелів, плакатів, емблем або символів. Батьки відповідатимуть штрафом у розмірі від 5 до 30 базових величин, якщо їхні діти братимуть участь в несанкціонованих заходах [ 10] .

28 травня 2021 року прийнято Закон Республіки Білорусь № 114-3 «Про зміну законів з питань трудових відносин», яким внесено зміни до Трудового кодексу Республіки Білорусь та до Закону Республіки Білорусь від 5 січня 2016 року № 354-3 «Про промислову безпеку», що набрали чинності з 30 червня 2021 року.

У частині питань дисциплінарної відповідальності пункт 7 статті 42 Трудового кодексу доповнено новими підставами звільнення за ініціативою роботодавця, зокрема: примушення працівників до участі в страйку, створення іншим працівникам перешкод для виконання їхніх трудових обов'язків, заклики працівників до припинення виконання трудових обов'язків без поважних причин; участь працівника в незаконному страйку, а також в інших формах відмови працівника від виконання трудових обов' язків (повністю чи частково) без поважних причин.

Цим законом також внесені зміни до статті 46 Трудового кодексу, якими виключено необхідність попереднього повідомлення профспілки при розірванні тру- дового договору з працівником по зазначених підставах звільнення. Змінами до статті 388 Трудового кодексу забороняється під час проведення страйків висування політичних вимог. 3 урахуванням змін до статті 395 Кодексу рішення суду про визнання страйку незаконним чи рішення про його проведення підлягає негайному виконанню. У чинній редакції статті 388 Трудового кодексу визначено, що спеціальним законом можуть бути встановлені обмеження реалізації права на страйк у такій мірі, у якій це необхідно в інтересах національної безпеки, громадського порядку, здоров'я населення, прав та свобод інших осіб. 3 метою виключення можливих негативних наслідків як для підприємства та його працівників, так і для суспільства в цілому, Законом встановлено заборону на проведення страйків на підприємствах, що мають небезпечні виробничі об'єкти [11].

Таким чином, внаслідок підміни понять на національному рівні відбувається викривлення самої суті права на свободу зібрань, свободу вираження поглядів, прикриваючись інтересами національної безпеки, громадського порядку, забезпечення прав і свобод інших осіб, що є свідченням свавільної та репресивної поведінки держави.

Білоруський експерт Михайло Пастухов, аналізуючи виконання Республікою Білорусь рішень Комітету ООН з прав людини, зазначав: «Білоруська влада не вважає ці рішення обов'язковими для себе, що викликає зростаючу тривогу в апараті комітету» [ 12].

Очевидно, що в таких умовах можна говорити про низьку ефективність чинного універсального міжнародно-правового механізму захисту права на свободу мирних зібрань та суміжних прав, який напрацьований у Міжнародному пакті про громадянські та політичні права та Факультативному протоколі до нього. А відтак посилити такий механізм можливо шляхом застосування міжнародно-правової відповідальності за порушення державою взятих міжнародних зобов’ язань, у тому числі й щодо забезпечення прав людини. 
Закріпивши право на мирні зібрання в статті 39 Основного Закону, Україна взяла на себе зобов'язання щодо його забезпечення, а також гарантувала невтручання у здійснення цього права, окрім як відповідно до закону.

Слід зазначити, що серед розглянутих Комітетом ООН з прав Аюдини станом на сьогодні справ стосовно порушення Україною міжнародних зобов'язань 3 прав людини немає справ щодо права на мирні зібрання. Утім, це зумовлено не відсутністю фактів порушення права, а наявною можливістю застосування більш дієвих міжнародно-правових механізмів його захисту на регіональному рівні, як то звернення до Свропейського Суду з прав людини. Водночас у контексті досліджуваного питання варто звернути увагу на зауваження загального порядку стосовно сьомої періодичної доповіді України, розгляд якої здійснено на 2980 та 2981 засіданнях Комітету 8 та 9 липня 2013 року [ 13] .

Отже, Комітет ООН з прав людини висловив стурбованість відсутністю внутрішньої нормативно-правової бази, яка регулює право на мирні зібрання, та застосування національними судами застарілих правил, які не відповідають міжнародним стандартам і суттєво обмежують право на свободу зібрань. Він також занепокоєний повідомленнями про те, що звернення до суду місцевих органів влади з метою заборони мирних зібрань можуть бути задоволені в $90 \%$ випадків. Комітет відзначив, що в парламент був поданий законопроєкт про порядок організації та проведення мирних зібрань (стаття 21).

Комітет зазначив, що державі-учасниці треба забезпечити, щоб громадяни повною мірою користувались своїм правом на свободу зібрань; потрібно прийняти закон, що регулює свободу зібрань, який передбачає лише такі обмеження, які відповідають суворим вимогам статті 21 Пакту.

Разом з тим, дотепер в Україні такий закон не прийнятий.

Зауважимо, що відповідно до частини п’ятої статті 55 Конституції України кожен має право після використання всіх національних засобів юридичного захисту зверта- тися за захистом своїх прав і свобод до відповідних міжнародних судових установ чи до відповідних органів міжнародних організацій, членом або учасником яких є Україна.

За змістом статті 2 Закону України «Про судоустрій і статус суддів» від 02 червня 2016 року № 1402-VIII суд, здійснюючи правосуддя на засадах верховенства права, забезпечує кожному право на справедливий суд та повагу до інших прав і свобод, гарантованих Конституцією і законами України, а також міжнародними договорами, згода на обов'язковість яких надана Верховною Радою України.

Частиною восьмою статті 13 Закону України «Про судоустрій і статус суддів» установлено, що судові рішення інших держав, рішення міжнародних арбітражів, рішення міжнародних судових установ та аналогічні рішення інших міжнародних організацій щодо вирішення спорів $€$ обов'язковими до виконання на території України за умов, визначених законом, а також відповідно до міжнародних договорів, згода на обов'язковість яких надана Верховною Радою України.

Законом України «Про виконання рішень та застосування практики Свропейського суду з прав людини» 23 лютого 2006 року N 3477-IV врегульовані відносини, що виникають у зв'язку з обов'язком держави виконати рішення Європейського суду з прав людини у справах проти України; 3 необхідністю усунення причин порушення Україною Конвенції про захист прав людини і основоположних свобод і протоколів до неї; з впровадженням в українське судочинство та адміністративну практику європейських стандартів прав людини; зі створенням передумов для зменшення числа заяв до Свропейського суду з прав людини проти України.

Зокрема, у статті 10 цього Закону встановлено, що з метою забезпечення відновлення порушених прав Стягувача, крім виплати відшкодування, вживаються додаткові заходи індивідуального характеру.

Додатковими заходами індивідуального характеру $є$ :

a) відновлення настільки, наскільки це можливо, попереднього юридичного стану, 
який Стягувач мав до порушення Конвенції (restitutio in integrum);

б) інші заходи, передбачені у Рішенні.

Відновлення попереднього юридичного стану Стягувача здійснюється, зокрема, шляхом:

a) повторного розгляду справи судом, включаючи відновлення провадження у справі;

б) повторного розгляду справи адміністративним органом.

На відміну від чіткого законодавчого врегулювання виконання Україною рішень Європейського Суду з прав людини, можна констатувати, на жаль, що для виконання рішень Комітету ООН з прав людини в Україні відповідний правовий механізм нині відсутній взагалі.

Вважаємо, що усунути означену прогалину в національному законодавстві було 6 можливим шляхом, зокрема, внесення змін до процесуальних кодексів України, передбачивши, що міркування Комітету ООН з прав людини, у яких встановлені порушення Україною міжнародно-правових зобов’язань при розгляді справи, є підставою для перегляду судового рішення національним судом.

\section{Висновки}

Підсумовуючи наведене, зазначимо, що зауваження загального порядку та міркування Комітету ООН з прав людини за результатами розгляду індивідуальних повідомлень про порушення прав людини, гарантованих Міжнародним пактом про громадянські і політичні права, у тому числі й права на мирні зібрання, не мають обов'язкової юридичної сили, що свідчить про їхню недосконалість. Однак важливо, що такі рішення Комітету не лише спонукають держави до вжиття належних заходів щодо відновлення порушених прав конкретної особи, яка зверталася за міжнародно-правовим захистом, а також містять вказівку на необхідність приведення національного законодавства у відповідність до міжнародно-правових стандартів. Водночас подальша реалізація висловлених Комітетом рекомендацій залежить від волі держав-учасниць, які взяли на себе відповідний юридичний обов'язок до вжиття на- лежних та достатніх засобів правового захисту. Отже, досягти належної ефективності чинних міжнародно-правових механізмів захисту права на мирні зібрання можливо шляхом прийняття на національному рівні матеріально-правових норм, що регулюють захист права на мирні зібрання, відповідно до міжнародно-правових стандартів та доповнення чинних процесуально-правових норм щодо підстав перегляду судового рішення в разі встановлення Комітетом $\mathrm{OOH}$ 3 прав людини порушення державою-учасницею відповідних міжнародно-правових зобов’ язань.

\section{Мітература}

1. Конституція України // [Електронне посилання] https://zakon.rada. gov.ua/laws/show/254\% D $0 \%$ B A/ 96 $\% \mathrm{D} 0 \% \mathrm{~B} 2 \% \mathrm{D} 1 \% 80 \# \mathrm{n} 5253$

2. Українська дипломатична енциклопедія: у 2 т./Київ.нац.ун-т імені тараса Шевченка, Ін-т міжнарод. відносин; редкол. А.В. Губерський (голова) та ін. Київ: Знання України, 2004. Т.1. - 2004. 655 с.

3. Загальна декларація прав людини // [Електронне посилання] https://zakon.rada. gov.ua/laws/show/995_015\#o59

4. Міжнародний пакт про громадянські і політичні права // [Електронне посилання] https://zakon.rada.gov.ua/laws/ show/995_043\#Text

5. Факультативний протокол до Міжнародного пакту про громадянські і політичні права // Електронний ресурс: https://zakon. rada.gov.ua/laws/card/995_086

6. Зауваження загального порядку Комітету ООН з прав людини № 37 від 17 вересня 2020 року // Електронний реcypc: http://docstore.ohchr.org/SelfServices/ FilesHandler.ashx?enc $=6 \mathrm{QkG1d} / \mathrm{PPRiCAqhK}$ b7yhsrdB0H115979OVGGB + WPAXj3 + ho0P5 1AAHSqSubYW2/ROAag545hCEpG5u5zQsD pYQPUYSNeyb456XRPbWnwZ+ pk4wqETaf0 37bwQ9eOWaCR

7. Міркування Комітету $\mathrm{OOH} з$ прав людини за розглядом повідомлення№ 2461/2014 // Електронний ресурс: https:// juris.ohchr.org/Search/Details/2854

8. Міркування Комітету ООН з прав людини за розглядом повідомлення- 
№ 1949/2010 // Електронний ресурс: https:// juris.ohchr.org/Search/Details/1960

9. Міркування Комітету ООН з прав людини за розглядом повідомлення№ 2230/2012 // Електронний ресурс: https:// juris.ohchr.org/Search/Details/2531

10. Електронний ресурс: https://www. dw.com/uk/900-yevro-shtrafu-v-bilorusiposylyly-vidpovidalnist-za-uchast-uprotestakh/a-56737230

11. Електронний ресурс: https://mintrud. gov.by/ru/news_ru/view/press-reliz-k-zakonurespubliki-belarus-ot-28-maja-2021-g--114-zob-izmenenii-zakonov-po-voprosam-trudovyxotnoshenij_4083/
12. Пастухов М. Обращение к читателю/ Вестник прав человека. - 2010. - № 1. - С. 4.

13. Зауваження загального порядку Комітету ООН з прав людини стосовно сьомої періодичної доповіді України8 та 9 липня 2013 року // Електронний реcypc: https://tbinternet.ohchr.org/_layouts/15/ treatybodyexternal/Download.aspx?symbolno $=\mathrm{CCPR} \% 2 \mathrm{fC} \% 2 \mathrm{fUKR} \% 2 \mathrm{fCO} \% 2 \mathrm{f} 7 \& \mathrm{Lang}=\mathrm{ru}$

14. Закон України «Про судоустрій і статус суддів» // Електронний ресурс: https:// zakon.rada.gov.ua/laws/show/1402-19\#n6

15. Закон України «Про виконання рішень та застосування практики Європейського суду з прав людини» // Електронний ресурс: https://zakon.rada.gov.ua/ laws/show/3477-15\#o73 